\title{
Quality characteristics of fermented vinegar prepared with Seomaeyaksuk (Artemisia argyi H.) extract
}

\author{
Ji Hyeon Shin ${ }^{1}$, Min Jung Kang ${ }^{1}$, Hee Uk Byun ${ }^{1}$, Won Yoel Bea ${ }^{2}$, \\ Jeong Yeon Shin ${ }^{3}$, Weon Tack Seo ${ }^{3}$, Jine Shang Choi ${ }^{3}$, Jung Hye Shin ${ }^{1 *}$ \\ ${ }^{1}$ Namhae Garlic Research Institute, Namhae 52430, Korea \\ ${ }^{2}$ Artemisia Argyi H Agricultural Association Corporation, Namhae 52432, Korea \\ ${ }^{3}$ Department of Food Science, Gyeongnam National University of Science and Technology, Jinju 52725, Korea
}

\section{섬애약쑥 주정 추출물로 제조한 발효식초의 품질특성}

\author{
신지현 ${ }^{1} \cdot$ 강민정 $^{1} \cdot$ 변희 욱 $^{1} \cdot$ 배원열 $^{2} \cdot$ 신정연 $^{3} \cdot$ 서원택 $^{3} \cdot$ 최진상 $^{3} \cdot$ 신정혜 $^{1 *}$ \\ ${ }^{1}$ (재)남해마늘연구소, ${ }^{2}$ 섬애약쑥영농조합법인, ${ }^{3}$ 경남과학기술대학교 식품과학부
}

\begin{abstract}
This study was carried out to investigate the quality characteristics of vinegars containing jaceosidin and eupatilin using Artemisia argyi $\mathrm{H}$. ethanol extract (AEE). 10\% malt extract (ME) and water extract of Artemisia argyi $\mathrm{H}$. (AWE) were also prepared for vinegar production. Three kinds of materials were mixed in the same amount to prepare vinegar as follows; CO (ME, water, 18\% edible ethanol), SE (ME, water, and AEE), SW (ME, AWE, and $18 \%$ edible ethanol) and SM (ME, AWE, AEE). All samples were fermented by Acetobacter pasteurianus $\mathrm{A8}$ at $30^{\circ} \mathrm{C}$ for 25 days and analyzed at $10,15,20$ and 25 days. The $\mathrm{pH}$ decreased significantly during the fermentation. pH was lower in SE and SM than CO and SW. The acidity increased significantly during the fermentation, and was highest in SM (4.44\%) at 25 days of fermentation. The concentration of acetic acid was higher than other organic acids for all vinegars. Jaceosidin and eupatilin were not detected in both $\mathrm{CO}$ and $\mathrm{SW}$, but both were detected in the SE and SM. At 25 days of fermentation, jaceosidin and eupatilin concentrations in SE and SM were 6.49-6.88 $\mathrm{mg} / \mathrm{kg}$ and $2.23-2.24 \mathrm{mg} / \mathrm{kg}$, respectively. From these results, we confirmed that production of vinegar containing jaceosidin, eupatilin and phenolic compounds can be prepared by using Artemisia argyi $\mathrm{H}$. edible ethanol extract.
\end{abstract}

Key words : Seomaeyaksuk, jaceosidin, eupatilin, vinegar, acetic acid fermentation

\section{서 론}

식초는 오랜 역사를 지닌 전통 발효식품으로 음식을 조 리할 때 신맛을 내게 하는 조미료로 사용되는 것은 물론 짠맛, 단맛 등의 음식 맛을 부드럽게 하며 특유의 향미를 부여한다(1). 또한, 생체 내에서 호기적으로 쉽게 분해될 수 있고, 생리적 상태에 따라서 필요한 물질로 쉽게 전환

*Corresponding author. E-mail : whanbee@daum.net Phone : 82-55-860-8947, Fax : 82-55-860-8960

Received 5 June 2017; Revised 23 August 2017; Accepted 24 August 2017.

Copyright (c) The Korean Society of Food Preservation. All rights reserved.
될 수 있으며, 필요한 미량금속이 염으로 흡수될 수 있어 최근에는 영양학적으로 다량 섭취가 권장되고 있다(2). 초 산을 주성분으로 하여 각종 유기산류, 당류, 아미노산류, 에스테르류 등을 함유하고 있으며, 이와 같은 식초 성분들 은 젖산분해 촉진, 콜레스테롤 저하, 체지방 감소 및 식품성 분 내의 비타민 $\mathrm{C}$ 보호 작용 등의 효능이 있는 것으로 보고 되고 있다(3). 식초의 품질은 원료의 종류, 사용 균주, 발효 조건, 제조방법 등에 따라 크게 달라지며, 이에 따라 초산 함량, 유기산과 아미노산의 조성 등 식초의 화학성분도 영 향을 받는 것으로 알려져 있다(4).

쑥은 국화과(Compositae) 쑥속(Artemisia)에 속하는 다년 생 초본으로 한국, 중국, 일본 등 아시아 지역과 유럽 등지에 널리 분포하고 있으며(5), 우리나라에는 40여종의 Artemisia 
속이 자생하고 있는 것으로 보고되어 있다(6). 이 중 대표적 인 쑥 품종으로는 뺑쑥, 산쑥, 개똥쑥, 개사철쑥, 사철쑥, 더위지기, 맑은대쑥, 참쑥, 인지쑥, 황해쑥, 제비쑥 등이 있 으며, 이들의 주요 화합물이나 생육특성 및 생리활성이 서 로 상이하다(7).

섬애약쑥(Artemisia argyi H.)은 해풍과 풍부한 일조량 등으로 쑥 재배에 적합한 기후조건을 갖추고 있는 경남 남해군에서 자생되고 있는 황해쑥의 일종으로 '섬애 (Saomae)쑥'이란 품종 명으로 산림청 품종보호등록(제 42 호, 2013.09.27.) 된 자원이다(8). 섬애약쑥에 함유되어 있는 페놀 화합물은 높은 라디칼 소거 및 과산화지질 억제활성을 가지는 것으로 보고되어 있으며(9), 국내의 다른 약쑥에 비해 eupatilin은 약 $20 \%$ 정도, jaceosidin은 약 2 배정도 더 많이 함유되어 있는 것으로 알려져 있다(10). Eupatilin과 jaceosidin은 약쑥의 기능성 성분으로 eupatilin은 위궤양과 장질환, 위암치료 및 췌장, 간질병 치료에 효과적인 대표적 약리성분으로 알려져 있으며(11), jaceosidin은 강력한 항산 화력과 함께 항암, 항염증 작용을 갖는 것으로 보고되고 있다(12). Park 등(12)은 약쑥의 기능성 성분인 jaceosidin이 제 1형 당뇨병에서 간의 항산화 효소계를 활성화시킴으로 써 공복혈당을 낮추고, 인슐린 민감성을 증가시켜 당뇨병 이나 당뇨로 인한 합병증 예방 및 치료에 활용될 수 있을 것으로 보고하였으며, $\mathrm{Ha}$ 등(8)은 섬애약숙 $60 \%$ 에탄올 추출물이 eupatilin과 jaceosidin 등의 페놀 화합물에서 기인 되는 항산화 효과들로 뇌 신경세포 보호효과와 $\mathrm{AChE}$ (acethylcholine estetase) 억제 효과 등이 있다고 보고한 바 있다. 이 외에도 섬애약쑥과 관련하여 Choi 등(13)의 채취시 기 및 가공방법에 따른 섬애약쑥의 이화학적 특성과 항산화 활성, Hwang 등(10)의 섬애약숙의 이화학적 특성 및 생리활 성, Hwang 등(14)의 건조 및 침출조건에 따른 섬애약쑥 침출물의 항산화활성, Kang 등(9)의 전처리 방법을 달리한 섬애약쑥 에탄올 추출물의 이화학적 특성 등에 대해 연구가 진행되어 있으나, 가공품 및 발효식품 등에 식품 원료로서 의 활용도를 높이기 위한 관련 연구는 부족한 실정이다. 본 연구에서는 섬애약쑥을 이용한 발효 식초 개발 및 그 품질특성을 검증하기 위한 연구를 수행함에 있어 에탄올 추출물에 존재하는 섬애약쑥의 유효성분인 jaceosidin과 eupatilin이 식초의 숙성 완료 후에도 일정량 이상 잔존 가능 한지를 확인하고자 섬애약쑥 $70 \%$ 주정 추출물과 물 추출물 의 혼합 여부를 달리하여 식초를 발효시키면서 발효 기간별 시료를 취하여 이화학적 특성 변화를 분석하였다.

\section{재료 및 방법}

\section{실험재료}

섬애약쑥(Seomaeyakssuk, A argyi H.)은 6월에 채취하여
이물질을 제거한 후 흐르는 물에서 2회 세척한 다음 통풍이 잘 되는 그늘진 곳에서 하루에 한번 씩 뒤집어 주면서 완전 건조 한 후 총 길이 $3 \mathrm{~cm}$ 이내로 절단한 다음 $160^{\circ} \mathrm{C}$ 정도에서 30 분 건열 덖음 처리하여 실험용 재료로 사용하였다. 전처 리된 섬애약쑥 추출에 사용된 주정은 우리주정(주)사의 95\% 발효주정을 사용하였다.

\section{초산 균주 및 종배양}

초산균은 본 연구진이 식초로부터 분리 - 동정한 후 보관 중인 Acetobacter pasteurianus A8 균주를 사용하여 GYCEA (3\% glucose, $0.5 \%$ yeast extract, $1 \% \mathrm{CaCO}_{2}, 4 \%$ ethanol, $1.5 \% \mathrm{agar}$ ) 배지에서 계대배양하며 사용하였다. 종배양은 엿기름 $200 \mathrm{~g}$ 을 정제수 $1 \mathrm{~L}$ 에 현탁시켜 $60^{\circ} \mathrm{C}$ 에서 2 시간 동안 당화시킨 후 여과하여 제조한 엿기름 당화액에 접종하 여 $30^{\circ} \mathrm{C}$ 의 진탕배양기(IS-971RF model, Jeiotech Co., Seoul, Korea)에서 $160 \mathrm{rpm}$ 으로 3 일간 진탕배양 하였다.

\section{식초 제조용 추출물의 제조}

전 처리된 섬애약쑥 중의 유효물질인 jaceosidin과 eupatiline의 추출 조건 확립을 위하여 섬애약쑥 $10 \mathrm{~g}$ 에 0 , $25,50,75,100 \%$ 로 농도를 달리한 에탄올을 가하여 100 $\mathrm{mL}$ 로 정용한 다음 30 분간 진탕 추출한 후 여과지(Filter paper, No. 2, Advantec, Tokyo, Japan)로 여과한 것을 다시 $0.45 \mu \mathrm{m}$ membrane filter로 여과한 후 jaceosidin과 eupatiline 분석용 시료로 하여 HPLC-DAD(Agilent 1260, Agilent technologies, Santa Clara, CA, USA)로 분석하였다(하단 분 석법 참조). 분석결과는 Table 1 과 같이 jaceosidin과 eupatiline은 추출 용매 중 주정의 함유 비율이 높을수록 더 높은 함량이었는데, 용매의 주정 농도가 $50 \%$ 일 때에 비해 $75 \%$ 일 때 이들의 용출률이 가장 크게 증가하였으므로 이들 성분이 적정량 함유되어 있으면서 식초 제조시 사용 량, 경제성 및 처리의 용이성 등을 고려하여 $70 \%$ 주정을 식초 제조를 위한 섬애약쑥 추출용매로 선정하였다.

섬애약쑥 주정추출액은 섬애약쑥 무게 대비 30배의 $70 \%$ 주정을 가하여 24시간 정치 추출한 다음 여과하여 식초의 제조시 주정 농도 조절에 용이하도록 대용량 농축기(R-220,

Table 1. Jaceosidin and eupatilin contents of ethanol extract from Seomaeyaksuk (Artemisia argyi $\mathrm{H}$.)

$(\mathrm{mg} / 100 \mathrm{~g})$

\begin{tabular}{|c|c|c|c|c|c|}
\hline \multirow{2}{*}{ Item } & \multicolumn{5}{|c|}{ Ethanol concentration (\%) } \\
\hline & $0^{1)}$ & 25 & 50 & 75 & 100 \\
\hline Jaceosidin & $\mathrm{ND}$ & $9.2 \pm 0.3^{2) \mathrm{a} 3)}$ & $38.2 \pm 0.9^{b}$ & $80.4 \pm 1.8^{c}$ & $112.1 \pm 2.1^{d}$ \\
\hline Eupatilin & ND & $3.8 \pm 0.1^{\mathrm{a}}$ & $21.1 \pm 0.8^{\mathrm{b}}$ & $42.3 \pm 1.2^{\mathrm{c}}$ & $69.3 \pm 1.6^{d}$ \\
\hline
\end{tabular}


Buchi Labortechnik AG, Flawil, Switzerland)로 알코올을 제 거해 알코올 농도를 $18 \%$ 로 조절한 것을 섬애약쑥 주정추출 액으로 사용하였다. 물추출액은 섬애약쑥에 무게대비 20배 의 물을 가하여 24 시간 정치 추출한 후 여과하여 제조하였 다. 맥아추출액은 맥아에 부피대비 10 배의 물을 가하여 교 반하면서 5 시간 추출하여 사용하였다.

\section{섬애약쑥 주정 추출액의 첨가여부에 따른 식초의 제조}

섬애약쑥 식초 제조를 위한 추출물의 비율은 Table 2 와 같이 맥아추출액, 정제수 및 주정을 동량으로 혼합한 것을 대조군 $(\mathrm{CO})$ 으로 하였으며, 맥아추출액, 정제수, 섬애약쑥 주정추출액을 혼합한 것을 $\mathrm{SE}$, 맥아추출액, 섬애약쑥 물추 출액과 $18 \%$ 주정을 혼합한 것을 $\mathrm{SW}$, 맥아추출액, 섬애약쑥 의 물추출액과 주정추출액을 혼합한 것을 $\mathrm{SM}$ 군으로 구분 하여 각각의 발효기질을 제조하였다. 알코올 농도를 $6 \%$ 로 조정한 각각의 발효기질 $3 \mathrm{~L}$ 에 종배양한 초산균액을 $3 \%$ 접종하고, $30^{\circ} \mathrm{C}$ 에서 정치배양 하였다. 발효가 진행되면서 숙성 7-9일 이후에 초산균의 생육을 확인할 수 있는 균막이 생성되어 발효 10 일부터 5 일 간격으로 25 일까지 시료를 취하여 이화학적 특성을 분석하였다.

\section{색도 측정}

색도는 색차계(Ultra Scan VIS, Hunter Associates Laboratory Inc., Reston, VA, USA)로 측정한 후 Hunter scale 에 의해 L(lightness), a(redness), b(yellowness) 값으로 나타 내었다. 각 실험군별로 5개 이상의 시료에 대한 색도를 측정 하였으며, 이때 사용된 표준 백판의 $\mathrm{L}$ 값은 $99.41, \mathrm{a}$ 값은 $-0.19, \mathrm{~b}$ 값은 -0.06 이었다. 전체적인 색차를 나타내는 $\Delta \mathrm{E}$ 값은 Hunter-Scofield식 $\left(\Delta \mathrm{E}=\sqrt{\triangle L^{2}+\Delta a^{2}+\Delta b^{2}}\right)$ 으로 산출하였다.

\section{$\mathrm{pH}$ 및 산도}

$\mathrm{pH}$ 와 산도는 시료 $5 \mathrm{~g}$ 에 증류수를 가해 $50 \mathrm{~mL}$ 로 만든 다음 잘 혼합한 후 여과지(filter paper, No. 2, Advantec, Tokyo, Japan)로 여과한 여액을 자동적정기(G20 compact titrator, Mettler Toledo, Greifensee, Switzerland)로 동시에 측정하였다. 적정산도는 $0.1 \mathrm{~N} \mathrm{NaOH}$ 용액으로 시료액의 $\mathrm{pH}$ 가 8.4가 될 때까지 적정하여 초산 양으로 환산하였다.

\section{유리당 함량 분석}

시료 $5 \mathrm{~g}$ 에 3 차 증류수 $30 \mathrm{~mL}$ 을 가하고, 30분간 sonication 하였다. 여과지로 여과한 후, $0.45 \mu \mathrm{m}$ syringe filter로 여과하 여 HPLC-ELSD(Agilent 1260 infinity, Agilent, Santa Clara, $\mathrm{CA}, \mathrm{USA}$ )로 분석하였다. 분석용 column은 cosmosil sugar-D $(4.6 \times 250 \mathrm{~mm}$, Nacalai Tesque Inc., Kyoto, Japan)를 사용하 였고, 이동상은 water와 acetonitrile을 $3: 7(\mathrm{v} / \mathrm{v})$ 의 비율로 혼 합한 것을 사용하였다. 이동상의 속도는 $1.0 \mathrm{~mL} / \mathrm{min}$, 시료 주입량은 $10 \mu \mathrm{L}$, 검출기는 $\mathrm{ELSD}$ (Agilent $1260 \mathrm{ELSD}$, Agilent)를 사용하였고, 분석조건 온도는 $30^{\circ} \mathrm{C}$, 가스는 질소 를 사용하였다.

\section{유기산 함량 분석}

각각의 시료를 여과지로 여과후 시료액을 일정량 취하여 $0.45 \mu \mathrm{m}$ membrane filter로 여과한 다음 HPLC-DAD(Agilent 1260 , Agilent technologies)로 분석하였다. 분석용 컬럼은 Watchers 120 ODS-BP $(4.6 \times 250 \mathrm{~mm}, 5 \mu \mathrm{m}$, Watchers, Daiso Chemical Co., Tokyo, Japan)를 사용하였고, 이동상 용매는 $0.1 \% \mathrm{H}_{3} \mathrm{PO}_{4}$ 수용액을 $0.5 \mathrm{~mL} / \mathrm{min}$ 의 속도로 주입하였으며, 분석온도는 $30^{\circ} \mathrm{C}$ 를 유지하였고, $10 \mu \mathrm{L}$ 의 시료를 주입하여 $210 \mathrm{~nm}$ 에서 UV 검출기를 이용하여 검출하였다. 총 11 종의 유기산(citric acid, oxalic acid, tartaric acid, formic acid, malic acid, glutaric acid, lactic acid, acetic acid, fumaric acid, succinic acid, propionic acid) 표준물질을 시료와 동일한 조 건에서 분석하여 머무름 시간을 비교해 확인하였으며, 각 각의 검량곡선으로부터 그 함량을 산출하였다.

\section{페놀 화합물, jaceosidin 및 eupatilin의 함량분석}

각각의 시료를 여과지로 여과 후 시료액을 일정량 취하 여 $0.45 \mu \mathrm{m}$ membrane filter로 여과한 후 HPLC-DAD (Agilent 1260, Agilent technologies)로 분석하였다. 분석용 column은 zorbax SB-C ${ }_{18}(4.6 \times 250 \mathrm{~mm}, 5 \mu \mathrm{m}$, Agilent Technologies)을 사용하였고, 시료 주입량은 $10 \mu \mathrm{L}$ 로 하였 으며, 이동상 용매는 $0.1 \%$ formic acid 수용액과 acetonitrile 에 용해한 $0.1 \%$ formic acid를 시간에 따라 혼합비율을 조절 하면서 분석하였다. 페놀 화합물의 분석을 위한 이동상의 속도는 $0.7 \mathrm{~mL} / \mathrm{min}$, 검출기의 파장은 $280 \mathrm{~nm}$ 로 조정하였으 며, jaceosidin과 eupatilin의 분석을 위해서 이동상의 속도를

Table 2. Mixing ratios of materials and extracts to make Seomaeyaksuk (Artemisia argyi H.) vinegar

\begin{tabular}{cccccc}
\hline Sample code & $\begin{array}{c}10 \% \text { Malt extract } \\
(\mathrm{ME})\end{array}$ & Water & $\begin{array}{c}18 \% \text { Edible ethanol } \\
(\mathrm{EE})\end{array}$ & $\begin{array}{c}\text { Artemisia argyi } \mathrm{H} . \\
\text { water extract (AWE) }\end{array}$ & $\begin{array}{c}18 \% \text { Artemisia argy } \mathrm{H} . \\
\text { edible ethanol extract (AEE) }\end{array}$ \\
\hline CO & 1 & 1 & 1 & - & - \\
SE & 1 & 1 & - & 1 & 1 \\
SW & 1 & - & 1 & 1 & - \\
SM & 1 & - & - & 1 & 1 \\
\hline
\end{tabular}


$1.0 \mathrm{~mL} / \mathrm{min}$ 로 하고 검출기 파장은 $340 \mathrm{~nm}$ 로 설정하였다. 각각의 분석 조건에서 농도별 표준물질을 시료와 동일하게 분석한 후 머무름 시간을 비교하여 표준검량곡선으로부터 그 함량을 산출하였다.

\section{통계처리}

모든 실험은 3 회 이상 반복하여 실시하였으며 실험으로 부터 얻은 결과는 SPSS 12.0(Statistical package for Social Science, IBM Corporation, Endicott, NY, USA)을 사용하여 분석하였다. 결과치는 실험군당 평균표준편차로 표시하 였고, 통계적 유의성 검정은 일원배치 분산분석(one-way analysis of variance)을 한 후 $\mathrm{p}<0.05$ 수준에서 Duncan's multiple range test를 시행하였다.

\section{결과 및 고찰}

\section{색도의 변화}

섬애약쑥 주정추출물과 물추출물을 첨가하여 제조한 식 초의 색도를 살펴본 결과는 Table 3 과 같다. 발효 0 일차의 명도는 $\mathrm{CO}$ 시료에서는 27.74 이었으나 섬애약쑥 추출물이 첨가된 SE, SW 및 SM시료에서는 31.20-31.94의 범위로 서로간에 유의차 없이 $\mathrm{CO}$ 시료에 비해 유의적으로 높았다.
발효 20 일까지는 명도에 큰 차이가 없었다가 발효 25 일차 에는 $\mathrm{CO}$ 시료가 46.60 으로 가장 높았으며, 섬애약쑥 물추출 물을 첨가한 $\mathrm{SW}$ 시료의 명도가 26.48로 가장 낮았다. 적색 도는 발효 전에는 -0.57-3.00의 범위이던 것이 발효 기간 동안 불규칙한 증감을 보였고, 발효 25일에는 -0.40-3.08의 범위였다. 황색도는 발효 0 일차에 1.95-8.68의 범위로 대조 군인 $\mathrm{CO}$ 시료에서 가장 낮았고 섬애약쑥 추출물을 첨가한 시료의 경우 $\mathrm{CO}$ 시료보다 3.8-4.35배 더 높았다. $\mathrm{CO}$ 시료에 서는 발효의 진행과 더불어 황색도가 점차 증가하여 발효 25 일차에는 12.38 이었으나 $\mathrm{SE}, \mathrm{SW}$ 및 SM시료는 발효 10-15일까지는 증가하는 경향을 보이다가 다시 감소하여 발효 25일에는 5.67-7.96의 범위였다. 색차 $(\Delta \mathrm{E})$ 는 발효 0 일 에 67.97-71.71로 $\mathrm{CO}$ 시료의 색차가 가장 컸으며 발효 25 일 에는 54.26으로 유의적으로 감소하였고, 물추출물이 첨가 된 SW시료는 유의적으로 증가하여 73.34였다.

색도는 외관상 품질을 판정하는데 중요한 요소 중의 하 나로, 발효방법 뿐만 아니라 원료에 따라서도 영향을 받는 다고 보고되고 있다(15,16). Lee 등(17)은 현미식초 제조 시 교반배양과 정치배양으로 발효조건을 달리하였을 때 명도와 적색도는 큰 차이가 없었으나 황색도는 정치배양 하였을 때 더 높았다고 보고 한 바 있으며, Seo 등(18)은 2단계 발효법으로 생산된 과일식초의 이화학적 특정을 비 교한 결과 매실, 사과, 감, 포도 식초의 명도는 25.53-72.63,

Table 3. Changes in Hunter's color value of Seomaeyaksuk (Artemisia argyi H.) ethanol extract added vinegar

\begin{tabular}{|c|c|c|c|c|c|c|}
\hline \multirow{2}{*}{ Item } & \multirow{2}{*}{ Sample code ${ }^{1)}$} & \multicolumn{5}{|c|}{ Fermentation period (day) } \\
\hline & & 0 & 10 & 15 & 20 & 25 \\
\hline \multirow{4}{*}{$\mathrm{L}$} & $\mathrm{CO}$ & $27.74 \pm 0.84^{2)(b 3) A 4)}$ & $26.05 \pm 0.57^{\mathrm{aA}}$ & $28.90 \pm 0.02^{\mathrm{cA}}$ & $27.09 \pm 0.06^{\mathrm{bA}}$ & $46.60 \pm 0.04^{d D}$ \\
\hline & SE & $31.94 \pm 0.45^{\mathrm{cB}}$ & $34.90 \pm 0.11^{\mathrm{eD}}$ & $29.29 \pm 0.14^{a B}$ & $33.95 \pm 0.06^{\mathbb{D}}$ & $30.80 \pm 0.03^{\mathrm{bB}}$ \\
\hline & SW & $31.20 \pm 0.02^{\mathrm{cB}}$ & $29.52 \pm 0.48^{\mathrm{bB}}$ & $32.91 \pm 0.22^{\mathrm{dC}}$ & $33.14 \pm 0.24^{\mathrm{dC}}$ & $26.48 \pm 0.05^{\mathrm{aA}}$ \\
\hline & SM & $31.63 \pm 0.18^{\mathrm{bB}}$ & $32.98 \pm 0.09^{\mathrm{dC}}$ & $34.15 \pm 0.15^{\mathrm{eD}}$ & $27.52 \pm 0.03^{\mathrm{aB}}$ & $31.96 \pm 0.04^{\mathrm{CC}}$ \\
\hline \multirow{4}{*}{$\mathrm{a}$} & $\mathrm{CO}$ & $0.24 \pm 0.24^{6 B}$ & $-0.41 \pm 0.06^{\mathrm{aA}}$ & $2.72 \pm 0.01^{\mathrm{d}}$ & $0.46 \pm 0.06^{\mathrm{CB}}$ & $-0.29 \pm 0.04^{\mathrm{aB}}$ \\
\hline & SE & $-0.57 \pm 0.06^{\mathrm{aA}}$ & $3.09 \pm 0.03^{\mathrm{eD}}$ & $0.11 \pm 0.05^{\mathrm{cB}}$ & $1.20 \pm 0.01^{\mathrm{dC}}$ & $-0.4 \pm 0.04^{\mathrm{bA}}$ \\
\hline & SW & $3.00 \pm 0.01^{\mathrm{dC}}$ & $0.03 \pm 0.01^{\mathrm{bB}}$ & $1.74 \pm 0.03^{\mathrm{cC}}$ & $-1.46 \pm 0.02^{\mathrm{aA}}$ & $3.08 \pm 0.02^{\mathrm{eD}}$ \\
\hline & SM & $-0.43 \pm 0.02^{\mathrm{bA}}$ & $1.50 \pm 0.01^{\mathrm{dC}}$ & $-1.19 \pm 0.04^{\mathrm{aA}}$ & $2.89 \pm 0.02^{\mathrm{eD}}$ & $0.03 \pm 0.00^{\complement C}$ \\
\hline \multirow{4}{*}{$\mathrm{b}$} & $\mathrm{CO}$ & $1.95 \pm 0.81^{\mathrm{aA}}$ & $2.15 \pm 0.02^{\mathrm{abA}}$ & $5.16 \pm 0.02^{\mathrm{cA}}$ & $2.69 \pm 0.09^{\mathrm{bA}}$ & $12.38 \pm 0.07^{\mathrm{dD}}$ \\
\hline & SE & $8.14 \pm 0.09^{\mathrm{CBC}}$ & $13.90 \pm 0.21^{\mathrm{eD}}$ & $6.33 \pm 0.06^{6 \mathrm{~B}}$ & $9.55 \pm 0.02^{\mathbb{D}}$ & $5.67 \pm 0.02^{\mathrm{aA}}$ \\
\hline & SW & $7.72 \pm 0.02^{\mathrm{cB}}$ & $7.10 \pm 0.11^{\mathrm{bB}}$ & $9.68 \pm 0.03^{\mathrm{eD}}$ & $8.95 \pm 0.06^{\mathrm{dC}}$ & $6.94 \pm 0.08^{\mathrm{B}}$ \\
\hline & SM & $8.68 \pm 0.04^{\mathrm{cC}}$ & $10.30 \pm 0.03^{\mathrm{eC}}$ & $9.17 \pm 0.04^{\mathrm{dC}}$ & $6.05 \pm 0.09^{\mathrm{aB}}$ & $7.96 \pm 0.06^{\mathrm{bC}}$ \\
\hline \multirow{4}{*}{$\Delta \mathrm{E}$} & $\mathrm{CO}$ & $71.71 \pm 0.81^{\mathrm{CB}}$ & $73.40 \pm 0.57^{\mathrm{dD}}$ & $70.77 \pm 0.02^{6 \mathrm{D}}$ & $72.38 \pm 0.05^{\mathrm{cC}}$ & $54.26 \pm 0.03^{\mathrm{aA}}$ \\
\hline & SE & $67.97 \pm 0.45^{\mathrm{bA}}$ & $66.08 \pm 0.14^{\mathrm{aA}}$ & $70.42 \pm 0.14^{\mathrm{dC}}$ & $66.18 \pm 0.06^{\mathrm{aA}}$ & $68.85 \pm 0.03^{\mathrm{CC}}$ \\
\hline & SW & $68.73 \pm 0.01^{\mathrm{bA}}$ & $70.27 \pm 0.48^{\mathrm{cC}}$ & $67.24 \pm 0.22^{a \mathrm{~B}}$ & $66.89 \pm 0.25^{\mathrm{aB}}$ & $73.34 \pm 0.04^{\mathbb{d D}}$ \\
\hline & SM & $68.34 \pm 0.18^{\mathrm{dA}}$ & $67.26 \pm 0.09^{\mathrm{bB}}$ & $65.92 \pm 0.14^{\mathrm{aA}}$ & $72.21 \pm 0.04^{\mathrm{eC}}$ & $67.93 \pm 0.04^{\mathrm{cB}}$ \\
\hline
\end{tabular}

${ }^{1)}$ Refer to the Table 2.

${ }^{2)}$ Each value represents mean $\pm \mathrm{SD}, \mathrm{n}=3$.

${ }^{3) a-e}$ Means with different superscript in the same sample code are significantly different at $p<0.05$.

${ }^{4) A-D}$ Means with different superscript in the same fermentation days are significantly different at $p<0.05$. 
적색도 -0.36-27.81, 황색도 1.09-39.94로 원료과일 자체가 지니는 고유의 색에 따라 색도에 차이가 있었다고 보고 하였다. 본 연구의 섬애약쑥 식초도 원료인 쑥 추출물의 첨가 여부에 따라 발효 초기부터 유의적인 차이가 있었으 며, 명도와 황색도는 물추출물과 주정추출물 간에 차이가 적었으나 적색도의 경우 주정추출물이 첨가되었을 때 유의 적으로 낮았다.

\section{$\mathrm{pH}$ 의 변화}

섬액약쑥 추출물의 종류를 달리하여 발효한 식초의 $\mathrm{pH}$ 변화는 Table 4 와 같다. 발효 전에는 $\mathrm{CO}$ 시료에서 5.14로 $\mathrm{pH}$ 가 가장 높았으며, 섬애약쑥 추출물을 첨가한 $\mathrm{SE}, \mathrm{SW}$ 및 SM시료에서는 4.47-4.64의 범위였다. 식초 발효가 진행 되면 ethanol 함량은 감소하고, 유기산의 생성으로 $\mathrm{pH}$ 는 감소하는데(19), 본 연구에서도 발효가 진행됨에 따라 모든 시료가 점차 산성화 되는 경향이었다. 발효초기에 섬애약 쑥 주정추출물을 첨가한 $\mathrm{SE}$ 및 $\mathrm{SM}$ 시료의 $\mathrm{pH}$ 감소가 더디 게 진행 되었으나, 발효 20 일 이후부터 급격히 감소하였다. 발효말기 $\mathrm{pH}$ 는 섬애약쑥 주정추출물을 첨가하지 않은 $\mathrm{CO}$ 및 $\mathrm{SW}$ 시료에서 각각 3.06 및 3.05 였으며, 섬애약쑥 주정추 출물을 첨가한 $\mathrm{SE}$ 및 $\mathrm{SM}$ 시료는 각각 3.11 및 3.12로 유의적 인 차이를 보였다.
Kwon 등(20)은 감식초의 $\mathrm{pH}$ 는 2.85-3.22, 사과식초는 2.46-3.14의 범위라고 보고한 바 있으며, $\mathrm{Na}$ 등(21)은 원료 가 다른 시판식초의 $\mathrm{pH}$ 를 측정한 결과 2.39-3.60의 범위로 감식초가 가장 높았으며 양조식초, 무화과식초, 쌀식초, 사 과식초, 현미식초, 매실식초 순으로 나타나 첨가하는 원료 에 따라 식초의 $\mathrm{pH}$ 가 유의적인 차이를 보인다고 하였다. 본 연구의 섬애약쑥 식초는 발효 전에는 원료인 섬애약쑥 추출물의 영향을 받아 무첨가군인 CO 시료에 비해 유의적 으로 $\mathrm{pH}$ 가 낮았으나 발효가 진행되면서는 물추출물 첨가 군은 무첨가군과 유의적인 차이가 없었으며, 섬애약쑥 주 정추출물을 첨가하였을 때는 유의적으로 더 높아 쑥 추출물 자체의 첨가여부 보다는 추출물 제조를 위한 용매에 용출되 는 성분이 더 큰 영향을 미치는 것으로 추정된다.

\section{산도의 변화}

식품공전에서는 식초에 대한 품질규격으로 총산함량을 4-20\% 범위로 정하고 있고, 감식초는 예외적으로 $2.6 \%$ 이 상으로 규정하고 있다(22).

섬애약쑥의 식초의 숙성 과정 중 산도를 분석한 결과 (Table 5) 발효 0 일차의 산도는 $0.11-0.20 \%$ 의 범위이던 것이 발효 15 일에 CO 및 SW시료는 각각 $3.11 \%$ 와 $3.77 \%$ 였으며, 섬애약쑥 주정추출물이 첨가된 $\mathrm{SE}$ 및 $\mathrm{SM}$ 시료는 각각

Table 4. Changes in $\mathrm{pH}$ of Seomaeyaksuk (Artemisia argyi H.) ethanol extract added vinegar

\begin{tabular}{cccccc}
\hline \multirow{2}{*}{ Sample code ${ }^{1)}$} & \multicolumn{5}{c}{ Fermentation period (day) } \\
\cline { 2 - 6 } & 0 & 10 & 15 & 20 & 25 \\
\hline CO & $5.14 \pm 0.01^{2)(3) D 4}$ & $3.17 \pm 0.00^{\mathrm{CB}}$ & $3.10 \pm 0.01^{\mathrm{bB}}$ & $3.09 \pm 0.02^{\mathrm{bA}}$ & $3.06 \pm 0.02^{\mathrm{aA}}$ \\
SE & $4.64 \pm 0.01^{\mathrm{dC}}$ & $3.76 \pm 0.01^{\mathrm{CD}}$ & $3.46 \pm 0.01^{\mathrm{bD}}$ & $3.25 \pm 0.01^{\mathrm{bC}}$ & $3.11 \pm 0.01^{\mathrm{aB}}$ \\
SW & $4.54 \pm 0.01^{\mathrm{CB}}$ & $3.08 \pm 0.00^{\mathrm{bA}}$ & $3.04 \pm 0.00^{\mathrm{AA}}$ & $3.05 \pm 0.02^{\mathrm{aA}}$ & $3.05 \pm 0.02^{\mathrm{aA}}$ \\
SM & $4.47 \pm 0.01^{\mathrm{AA}}$ & $3.57 \pm 0.01^{\mathrm{dC}}$ & $3.32 \pm 0.01^{\mathrm{CC}}$ & $3.20 \pm 0.04^{\mathrm{bB}}$ & $3.12 \pm 0.01^{\mathrm{aB}}$ \\
\hline
\end{tabular}

\footnotetext{
${ }^{1)}$ Refer to the Table 2.
}

${ }^{2)}$ Each value represents mean $\pm \mathrm{SD}, \mathrm{n}=3$.

${ }^{3) a-c}$ Means with different superscript in the same sample code are significantly different at $p<0.05$.

${ }^{4) A-D}$ Means with different superscript in the same fermentation days are significantly different at $\mathrm{p}<0.05$.

Table 5. Changes in acidity of Seomaeyaksuk (Artemisia argyi H.) ethanol extract added vinegar

\begin{tabular}{cccccc}
\hline \multirow{2}{*}{ Sample code ${ }^{\mathrm{l})}$} & \multicolumn{5}{c}{ Fermentation period (day) } \\
\cline { 2 - 6 } & 0 & 10 & 15 & 20 & 25 \\
\hline CO & $0.11 \pm 0.01^{2 / \mathrm{a} 3) \mathrm{A} 4)}$ & $1.91 \pm 0.01^{\mathrm{bC}}$ & $3.11 \pm 0.01^{\mathrm{CC}}$ & $3.52 \pm 0.00^{\mathrm{dC}}$ & $3.60 \pm 0.01^{\mathrm{AA}}$ \\
SE & $0.14 \pm 0.01^{\mathrm{aB}}$ & $0.49 \pm 0.00^{\mathrm{bA}}$ & $0.95 \pm 0.01^{\mathrm{CA}}$ & $2.33 \pm 0.01^{\mathrm{dA}}$ & $3.81 \pm 0.09^{\mathrm{B}}$ \\
SW & $0.20 \pm 0.01^{\mathrm{aD}}$ & $2.92 \pm 0.01^{\mathrm{bD}}$ & $3.77 \pm 0.08^{\mathrm{CD}}$ & $3.96 \pm 0.04^{\mathrm{dD}}$ & $4.37 \pm 0.06^{\mathrm{C}}$ \\
SM & $0.16 \pm 0.01^{\mathrm{aC}}$ & $0.88 \pm 0.01^{\mathrm{bB}}$ & $1.96 \pm 0.09^{\mathrm{CB}}$ & $3.13 \pm 0.03^{\mathrm{dB}}$ & $4.44 \pm 0.12^{\mathrm{CC}}$ \\
\hline
\end{tabular}

\footnotetext{
${ }^{1)}$ Refer to the Table 2.
}

${ }^{2)}$ Each value represents mean $\pm \mathrm{SD}, \mathrm{n}=3$.

${ }_{3) \mathrm{a}-\mathrm{e}}$ Means with different superscript in the same sample code are significantly different at $\mathrm{p}<0.05$.

${ }^{4) A-D}$ Means with different superscript in the same fermentation days are significantly different at $p<0.05$. 
$0.95 \%$ 와 $1.96 \%$ 로 섬애약숙 주정추출물 첨가 시 초기 발효 가 더딘 것으로 나타났다. 그러나 그 이후부터는 섬애약쑥 주정추출물을 함유한 식초에서 발효가 원활히 진행되어 산도가 급격히 증가해 발효 25 일에는 SE시료가 $3.81 \%$ 로 대조구인 $\mathrm{CO}$ 시료(3.60\%) 보다 높았고, $\mathrm{SM}$ 시료는 $4.44 \%$ 로 시료 중 산도가 가장 높았다.

본 연구의 결과에서 섬애약쑥 주정추출물이 첨가된 시료 들이 초기 발효가 지연된 것은 쑥 추출물의 항균작용에 기인한 것으로 추측되는데, Park 등(23)은 쑥의 물 및 에탄 올 추출물의 항균활성을 조사한 결과 물 추출물은 시험균주 에 대한 항균활성이 없었으나, 에탄올 추출물의 경우 그람 양성균인 L. monocytogenes 와 S. aureus에 대하여 생육저해 환을 형성하였다고 보고한 바 있다. 또한 쑥으로부터 정제 된 물질인 o-coumaric acid와 유도체인 m-, p-coumaric acid 의 항균활성을 조사한 결과 그람 음성 및 양성균 모두에 대해 항균활성을 나타내는데, o-coumaric acid는 $B$. subtilis $(12.6-18.0 \mathrm{~mm})$ 와 $S$. typhimurium (12.6-16.6 mm)에 대하여 우수한 항균활성을 나타내었다고 보고되어 있다 (24). 쑥의 이러한 항균활성은 식초의 발효 초기 잡균 번식 을 방지하는데도 기여할 것으로 예상된다.

식초의 제조에서 초산균의 작용으로 생성되는 초산은 총산 함량을 좌우하여 품질판정 지표로 이용되고, 이 외에 다양한 유기산이 함께 함유되어 식초의 산미를 형성하게 된다(25). Lee 등(17)은 초산균주를 달리하여 제조한 흑찰 미 식초의 총 산도는 $3.60-7.85 \%$ 로 균주의 발효능력에 따라 산도에 차이가 난다고 보고하였으며, $\mathrm{Na}$ 등(21)은 시판 발 효식초의 원료에 따른 특성을 조사한 결과 현미식초, 사과 식초, 매실식초의 총산도는 6.33-6.57의 범위였고 감식초, 양조식초, 쌀식초, 무화과 식초는 4.38-5.48의 범위로 식초 의 제조시 이용되는 원료의 종류, 사용량, 제조방법 등에 따라 다양한 결과를 보인다고 보고하였다. 본 연구의 결과 에서도 원료인 섬애약쑥 추출물의 첨가 유무 및 추출용매는 발효 속도와 산의 생성 정도에 영향을 미친 것으로 판단된 다.

\section{유리당의 변화}

섬애약쑥 추출물을 달리하여 제조한 식초의 유리당 함량 을 분석한 결과는 Table 6과 같다. 유리당은 fructose와 glucose 두 종류가 정량되었고, 발효기간이 경과할수록 유 리당의 함량은 점차 감소하는 경향이었는데 $\mathrm{CO}$ 시료의 유 리당 총량은 발효 전 $0.59 \mathrm{~g} / 100 \mathrm{~mL}$ 이던 것이 발효 25 일에는 $0.35 \mathrm{~g} / 100 \mathrm{~mL}$ 이었으며, 섬애약쑥 물추출물을 첨가한 $\mathrm{SW}$ 시료에서는 $0.61 \mathrm{~g} / 100 \mathrm{~mL}$ 이던 것이 $0.42 \mathrm{~g} / 100 \mathrm{~mL}$ 로 감소 하였다. 섬애약쑥 주정 추출물을 첨가한 SE는 $0.63 \mathrm{~g} / 100$ $\mathrm{mL}$ 이던 것이 발효 25 일에는 약 $40 \%$ 가 감소하여 $0.38 \mathrm{~g} / 100$ $\mathrm{mL}$ 이었으며, $\mathrm{SM}$ 시료는 발효 0 일에 $0.70 \mathrm{~g} / 100 \mathrm{~mL}$ 로 가장 높았는데 발효 10 일에는 $0.49 \mathrm{~g} / 100 \mathrm{~mL}$ 로 가장 큰 폭으로
감소한 후 발효 25 일에 잔존율은 약 $51 \%$ 정도 였다. 유리당 의 종류에 따른 감소를 살펴보면 glucose의 경우 모든 시료 에서 발효기간이 경과함에 따라 감소하는 경향이었으며, fructose의 경우 발효기간에 따른 유의차는 없었다.

Jang 등(26)은 교반 및 정치배양에 따른 사과식초의 유리 당으로 fructose와 glucose가 검출되었다고 하였으며, Moon 등(27)은 국내 시판 식초에는 glucose가 가장 많이 함유되어 있으며 다음으로는 fructose가 많다고 보고한 바 있으며, Lee와 $\operatorname{Kim}(15)$ 은 자연 발효를 통해 감식초를 제조하였을 때 원료 감에서 기인하는 fructose, glucose, sucrose 및 maltose는 발효를 거치면서 점차 그 함량이 감소하는데 그 중 glucose의 감소 폭이 가장 크고 fructose는 일정 초산발효 기간이 경과한 이후에는 그 함량도 낮고 거의 변화가 없다 고 보고한 바 있는데, 이들의 보고는 본 연구의 결과와도 일치하는 경향이었다.

Table 6. Changes in free sugar of Seomaeyaksuk (Artemisia argyi H.) ethanol extract added vinegar

\begin{tabular}{|c|c|c|c|c|}
\hline \multirow{2}{*}{$\begin{array}{c}\text { Sample } \\
\text { code }^{1)}\end{array}$} & \multicolumn{4}{|c|}{$(\mathrm{g} / 100 \mathrm{~mL})$} \\
\hline & $\begin{array}{l}\text { Ferment. period } \\
\text { (day) }\end{array}$ & Fructose & Glucose & Total \\
\hline \multirow{5}{*}{$\mathrm{CO}$} & 0 & $0.13 \pm 0.01^{2) \text { a3)A4) }}$ & $0.46 \pm 0.01^{\mathrm{cA}}$ & 0.59 \\
\hline & 10 & $0.16 \pm 0.04^{\mathrm{abA}}$ & $0.24 \pm 0.03^{\mathrm{bA}}$ & 0.40 \\
\hline & 15 & $0.14 \pm 0.01^{\mathrm{abA}}$ & $0.21 \pm 0.01^{\mathrm{aA}}$ & 0.35 \\
\hline & 20 & $0.14 \pm 0.01^{\mathrm{abA}}$ & $0.18 \pm 0.01^{\mathrm{aA}}$ & 0.32 \\
\hline & 25 & $0.17 \pm 0.01^{\mathrm{bA}}$ & $0.18 \pm 0.01^{\mathrm{aA}}$ & 0.35 \\
\hline \multirow{5}{*}{ SE } & 0 & $0.19 \pm 0.04^{\mathrm{aBC}}$ & $0.44 \pm 0.08^{\mathrm{dA}}$ & 0.63 \\
\hline & 10 & $0.19 \pm 0.04^{\mathrm{aA}}$ & $0.39 \pm 0.05^{\mathrm{cC}}$ & 0.58 \\
\hline & 15 & $0.19 \pm 0.05^{\mathrm{aA}}$ & $0.26 \pm 0.03^{\mathrm{bB}}$ & 0.45 \\
\hline & 20 & $0.22 \pm 0.03^{\mathrm{aB}}$ & $0.23 \pm 0.02^{\mathrm{bB}}$ & 0.45 \\
\hline & 25 & $0.19 \pm 0.08^{\mathrm{aA}}$ & $0.19 \pm 0.04^{\mathrm{aAB}}$ & 0.38 \\
\hline \multirow{5}{*}{ SW } & 0 & $0.16 \pm 0.01^{\mathrm{abAB}}$ & $0.45 \pm 0.03^{\mathrm{bA}}$ & 0.61 \\
\hline & 10 & $0.15 \pm 0.02^{\mathrm{aA}}$ & $0.23 \pm 0.01^{\mathrm{aA}}$ & 0.38 \\
\hline & 15 & $0.16 \pm 0.01^{\mathrm{abA}}$ & $0.21 \pm 0.01^{\mathrm{aA}}$ & 0.37 \\
\hline & 20 & $0.18 \pm 0.02^{\mathrm{abAB}}$ & $0.22 \pm 0.01^{\mathrm{aB}}$ & 0.40 \\
\hline & 25 & $0.19 \pm 0.02^{\mathrm{bA}}$ & $0.23 \pm 0.01^{\mathrm{aB}}$ & 0.42 \\
\hline \multirow{5}{*}{ SM } & 0 & $0.22 \pm 0.02^{2 \mathrm{C}}$ & $0.48 \pm 0.02^{\mathrm{dA}}$ & 0.70 \\
\hline & 10 & $0.18 \pm 0.05^{\mathrm{aA}}$ & $0.31 \pm 0.04^{\mathrm{CB}}$ & 0.49 \\
\hline & 15 & $0.17 \pm 0.05^{\mathrm{aA}}$ & $0.24 \pm 0.03^{\mathrm{bAB}}$ & 0.41 \\
\hline & 20 & $0.18 \pm 0.02^{\mathrm{aAB}}$ & $0.23 \pm 0.03^{\mathrm{bB}}$ & 0.41 \\
\hline & 25 & $0.17 \pm 0.01^{\mathrm{aA}}$ & $0.19 \pm 0.01^{\mathrm{aB}}$ & 0.36 \\
\hline
\end{tabular}

${ }^{1)}$ Refer to the Table 2

${ }^{2)}$ Each value represents mean $\pm \mathrm{SD}, \mathrm{n}=3$.

3)a-d Means with different superscript in the same sample code are significantly different at $\mathrm{p}<0.05$.

4) $\mathrm{A}-\mathrm{C}$ Means with different superscript in the same fermentation days are significantly different at $\mathrm{p}<0.05$. 


\section{유기산의 변화}

유기산은 식초의 산미와 지미에 영향을 주어 품질에 중 요한 영향을 미친다(28). 특히 식초의 양조과정 중 초산균의 작용에 의해 생성되는 acetic acid는 식초의 주성분으로 발 효 관리의 지침이 된다(27).

섬애약쑥 추출물의 종류를 달리하여 제조한 식초의 유기 산 함량을 분석한 결과는 Table 7과 같다. 섬애약쑥 식초에 서는 총 9종의 유기산이 검출되었는데 그 중 acetic acid 함량이 가장 높았고 다음으로 oxalic acid, succinic acid와 citric acid 함량이 유사한 범위였으며 formic acid, malic acid, lactic acid 3종류는 섬애약쑥 주정추출물의 첨가 유무와 저장기간에 따라 검출정도가 상이하였다. 즉, 섬애약쑥 주 정추출물이 첨가되지 않은 $\mathrm{CO}$ 및 $\mathrm{SW}$ 시료에서는 formic acid가 49.59-114.20 mg/100 mL이 검출되었고 malic acid는 검출되지 않았는데 주정추출물이 첨가된 $\mathrm{SE}$ 및 $\mathrm{SM}$ 시료에 서는 malic acid가 $18.96-117.77 \mathrm{mg} / 100 \mathrm{~mL}$ 이 검출되었고 formic acid는 검출되지 않았다. Lactic acid는 발효 0 일차에 $131.58-164.59 \mathrm{mg} / 100 \mathrm{~mL}$ 가 검출되었는데 발효 15 일 이후
부터는 모든 시료에서 검출되지 않았다. Acetic acid는 발효 0 일차에 $127.22-264.99 \mathrm{mg} / 100 \mathrm{~mL}$ 의 범위이던 것이, 발효 10 일에 $\mathrm{CO}$ 및 $\mathrm{SW}$ 시료는 각각 $2,134.43 \mathrm{mg} / 100 \mathrm{~mL}$ 및 $2,772.73 \mathrm{mg} / 100 \mathrm{~mL}$ 였으며, 주정추출물을 첨가한 $\mathrm{SE}$ 와 $\mathrm{SM}$ 시료는 각각 $226.24 \mathrm{mg} / 100 \mathrm{~mL}$ 및 $781.64 \mathrm{mg} / 100 \mathrm{~mL}$ 로 $\mathrm{CO}$ 및 SW시료의 9-36\% 정도에 불과했다. 발효기간이 경과 함에 따라 acetic acid는 점차 증가하여 발효 25 일에는 $3,638.51-4,532.90 \mathrm{mg} / 100 \mathrm{~mL}$ 범위로 $\mathrm{SM}$ 시료에서 가장 높 은 함량이었다. Oxalic acid는 발효기간이 경과함에 따라 점차 증가하였으며 섬애약쑥 주정추출물 첨가 시료가 미 첨가 시료보다 약 10 배 정도 함량이 더 높았다.

Joo 등(29)은 발효 현미 식초 제조시 acetic acid 외에 oxalic acid, citric acid, tartaric acid, malic acid, lactic acid 등이 검출되었으며 발효방법에 따라 유기산의 종류 및 함량 이 다소 차이를 나타낸다고 하였다. Yi 등(30)은 초산 발효 시 균주의 사멸기 동안 공급되는 영양분이 불충분할 경우 acetic acid 대신 부산물로 lactic acid가 생성되었다고 보고 였는데, 본 연구 결과에서 lactic acid는 발효와 더불어 불검

Table 7. Changes in organic acids of Seomaeyaksuk (Artemisia argyi H.) ethanol extract added vinegar

$(\mathrm{mg} / 100 \mathrm{~mL})$

\begin{tabular}{|c|c|c|c|c|c|c|c|c|c|c|}
\hline $\begin{array}{l}\text { Sample } \\
\text { code }^{1)}\end{array}$ & $\begin{array}{l}\text { Fermentation } \\
\text { period (day) }\end{array}$ & Oxalic acid & Formic acid & Malic acid & Lactic acid & Acetic acid & Citric acid & Succinic acid & Fumaric acid & Propionic acid \\
\hline \multirow{5}{*}{$\mathrm{CO}$} & 0 & $15.18 \pm 0.06^{22 \mathrm{a} 3)}$ & $49.59 \pm 0.31^{a}$ & $\mathrm{ND}^{4)}$ & $131.58 \pm 4.41$ & $232.21 \pm 1.63^{\mathrm{a}}$ & $57.95 \pm 1.39^{\mathrm{a}}$ & $244.84 \pm 1.99^{b}$ & $0.16 \pm 0.01^{\mathrm{a}}$ & $12.21 \pm 1.25^{\mathrm{c}}$ \\
\hline & 10 & $24.19 \pm 0.12^{c}$ & $102.42 \pm 0.98^{\mathrm{a}}$ & $\mathrm{ND}$ & ND & $2134.43 \pm 1.24^{b}$ & $139.78 \pm 0.56^{e}$ & $260.79 \pm 0.33^{c}$ & $0.54 \pm 0.01^{b}$ & $6.98 \pm 0.29^{\mathrm{a}}$ \\
\hline & 15 & $24.69 \pm 0.12^{\mathrm{d}}$ & $99.68 \pm 0.39^{\mathrm{b}}$ & $\mathrm{ND}$ & ND & $2700.42 \pm 2.01^{\mathrm{c}}$ & $104.30 \pm 0.81^{b}$ & $219.20 \pm 0.64^{\mathrm{a}}$ & $0.59 \pm 0.01^{b}$ & $7.77 \pm 0.21^{\mathrm{a}}$ \\
\hline & 20 & $23.12 \pm 0.17^{b}$ & $97.21 \pm 4.05^{c}$ & $\mathrm{ND}$ & ND & $2548.03 \pm 0.27^{\mathrm{d}}$ & $129.20 \pm 0.32^{\mathrm{c}}$ & $243.43 \pm 0.53^{b}$ & $0.55 \pm 0.01^{\mathrm{c}}$ & $10.32 \pm 0.46^{b}$ \\
\hline & 25 & $28.64 \pm 0.28^{\mathrm{e}}$ & $114.20 \pm 4.34^{c}$ & $\mathrm{ND}$ & ND & $3638.51 \pm 2.16^{e}$ & $110.35 \pm 1.15^{\mathrm{d}}$ & $296.20 \pm 5.14^{d}$ & $0.74 \pm 0.02^{\mathrm{d}}$ & $12.96 \pm 0.67^{c}$ \\
\hline \multirow{5}{*}{ SE } & 0 & $187.59 \pm 0.25^{\mathrm{a}}$ & $\mathrm{ND}$ & $21.03 \pm 0.76^{\mathrm{a}}$ & $161.23 \pm 4.34$ & $142.69 \pm 0.64^{a}$ & $69.66 \pm 1.60^{\mathrm{a}}$ & $299.27 \pm 1.91^{b}$ & $0.15 \pm 0.01^{\mathrm{a}}$ & $150.30 \pm 8.06^{b}$ \\
\hline & 10 & $194.67 \pm 0.29^{b}$ & $\mathrm{ND}$ & $22.32 \pm 0.81^{b}$ & $334.35 \pm 5.22$ & $226.24 \pm 1.07^{\mathrm{b}}$ & $90.75 \pm 1.41^{b}$ & $317.08 \pm 2.13^{\mathrm{d}}$ & $0.16 \pm 0.00^{\mathrm{a}}$ & $154.12 \pm 8.91^{\mathrm{b}}$ \\
\hline & 15 & $209.99 \pm 0.64^{d}$ & $\mathrm{ND}$ & $108.02 \pm 2.36^{\mathrm{c}}$ & ND & $1258.46 \pm 1.44^{\mathrm{d}}$ & $97.93 \pm 1.51^{\mathrm{c}}$ & $306.37 \pm 2.89^{c}$ & $0.22 \pm 0.01^{b}$ & $143.93 \pm 7.95^{b}$ \\
\hline & 20 & $208.87 \pm 0.24^{c}$ & $\mathrm{ND}$ & $101.92 \pm 1.11^{\mathrm{d}}$ & ND & $2232.18 \pm 4.15^{c}$ & $100.34 \pm 1.44^{c}$ & $285.68 \pm 1.70^{\mathrm{a}}$ & $0.26 \pm 0.01^{\mathrm{c}}$ & $120.64 \pm 7.22^{\mathrm{a}}$ \\
\hline & 25 & $220.73 \pm 0.42^{\mathrm{e}}$ & $\mathrm{ND}$ & $107.29 \pm 1.92^{\mathrm{e}}$ & $\mathrm{ND}$ & $3917.35 \pm 8.13^{\mathrm{e}}$ & $109.03 \pm 0.90^{\mathrm{d}}$ & $288.72 \pm 1.93^{\mathrm{a}}$ & $0.34 \pm 0.01^{\mathrm{d}}$ & $108.49 \pm 5.25^{\mathrm{a}}$ \\
\hline \multirow{5}{*}{ SW } & 0 & $16.54 \pm 0.10^{\mathrm{a}}$ & $50.14 \pm 0.22^{\mathrm{a}}$ & $\mathrm{ND}$ & $158.98 \pm 3.89$ & $264.99 \pm 2.49^{\mathrm{a}}$ & $63.93 \pm 1.15^{\mathrm{a}}$ & $236.74 \pm 1.15^{\mathrm{e}}$ & $0.19 \pm 0.00^{\mathrm{a}}$ & $49.54 \pm 3.39^{b}$ \\
\hline & 10 & $22.04 \pm 0.15^{b}$ & $57.22 \pm 0.23^{\mathrm{c}}$ & $\mathrm{ND}$ & ND & $2772.73 \pm 1.39^{b}$ & $100.35 \pm 0.54^{b}$ & $213.16 \pm 0.65^{\mathrm{a}}$ & $0.41 \pm 0.01^{\mathrm{b}}$ & $10.46 \pm 1.54^{\mathrm{a}}$ \\
\hline & 15 & $23.99 \pm 0.08^{c}$ & $61.08 \pm 0.23^{\mathrm{bc}}$ & $\mathrm{ND}$ & ND & $3904.12 \pm 3.58^{c}$ & $101.01 \pm 1.47^{\mathrm{bc}}$ & $218.27 \pm 0.68^{b}$ & $0.47 \pm 0.01^{\mathrm{c}}$ & $11.07 \pm 3.14^{\mathrm{a}}$ \\
\hline & 20 & $24.29 \pm 0.06^{\mathrm{d}}$ & $63.25 \pm 0.17^{b}$ & $\mathrm{ND}$ & ND & $3989.55 \pm 3.33^{\mathrm{d}}$ & $103.15 \pm 0.55^{c}$ & $224.65 \pm 0.57^{\mathrm{c}}$ & $0.48 \pm 0.01^{\mathrm{c}}$ & $13.66 \pm 3.60^{\mathrm{a}}$ \\
\hline & 25 & $24.72 \pm 0.08^{\mathrm{e}}$ & $64.51 \pm 0.23^{\mathrm{d}}$ & $\mathrm{ND}$ & ND & $4084.23 \pm 1.56^{\circ}$ & $102.83 \pm 1.74^{\mathrm{c}}$ & $228.20 \pm 0.33^{\mathrm{d}}$ & $0.50 \pm 0.01^{\mathrm{d}}$ & $108.49 \pm 5.25^{\mathrm{c}}$ \\
\hline \multirow{5}{*}{ SM } & 0 & $196.46 \pm 3.88^{\mathrm{a}}$ & $\mathrm{ND}$ & $51.99 \pm 3.06^{\mathrm{a}}$ & $164.59 \pm 3.07$ & $127.22 \pm 4.46^{\mathrm{a}}$ & $77.54 \pm 2.10^{\mathrm{a}}$ & $300.42 \pm 1.81^{b}$ & $0.18 \pm 0.00^{\mathrm{a}}$ & $49.54 \pm 3.39^{b}$ \\
\hline & 10 & $200.64 \pm 5.77^{\mathrm{a}}$ & $\mathrm{ND}$ & $18.96 \pm 0.91^{\mathrm{a}}$ & ND & $781.64 \pm 4.36^{b}$ & $100.15 \pm 0.81^{b}$ & $310.72 \pm 0.40^{\mathrm{c}}$ & $0.19 \pm 0.01^{\mathrm{a}}$ & $10.46 \pm 1.54^{\mathrm{a}}$ \\
\hline & 15 & $215.00 \pm 0.62^{b}$ & $\mathrm{ND}$ & $140.11 \pm 1.44^{c}$ & ND & $2460.76 \pm 2.06^{c}$ & $170.13 \pm 0.87^{c}$ & $295.71 \pm 2.08^{\mathrm{ab}}$ & $0.22 \pm 0.01^{b}$ & $11.07 \pm 3.14^{\mathrm{a}}$ \\
\hline & 20 & $222.39 \pm 0.63^{\mathrm{c}}$ & $\mathrm{ND}$ & $140.06 \pm 2.32^{b}$ & ND & $3616.56 \pm 3.77^{\mathrm{d}}$ & $178.42 \pm 0.93^{\mathrm{d}}$ & $291.13 \pm 1.11^{\mathrm{a}}$ & $0.26 \pm 0.01^{c}$ & $13.66 \pm 3.60^{\mathrm{a}}$ \\
\hline & 25 & $226.95 \pm 2.91^{c}$ & $\mathrm{ND}$ & $117.77 \pm 0.83^{\mathrm{c}}$ & ND & $4532.90 \pm 4.91^{\mathrm{e}}$ & $284.89 \pm 1.67^{\mathrm{e}}$ & $434.35 \pm 8.18^{d}$ & $0.30 \pm 0.01^{\mathrm{d}}$ & $146.69 \pm 5.60^{c}$ \\
\hline
\end{tabular}

\footnotetext{
${ }^{1)}$ Refer to the Table 2 .

${ }^{2)}$ Each value represents mean $\pm S D, n=3$.

${ }^{3) \text { ate }}$ Means with different superscript in the same sample code are significantly different at $p<0.05$.

${ }^{4)} \mathrm{ND}$, not detected.
} 
출 되었으며 acetic acid 함량이 급격히 증가하는 것으로 보아 섬애약쑥의 유효성분으로 인하여 잡균의 번식은 최소 화되고 정상적인 초산발효가 이루어진 것으로 판단된다.

\section{페놀화합물의 변화}

페놀화합물은 수산기를 가지는 방향성 화합물의 총칭으 로 식물계에 널리 분포하는 2 차 대사산물의 하나로서, 이들 은 세포벽, 다당류, 리그닌 등과 에스테르 결합되어 있거나 중합체로 존재한다(4). Hydroxyl기를 포함하고 있어 단백 질 또는 효소, 기타 거대 분자들과 결합하는 성질을 지니고, 이러한 성질은 미생물의 세포에 작용하여 성장저해를 유발 시켜 항미생물 활성을 보이며, 항산화 효과로 이어지기도 한다(6).

섬애약쑥 식초의 페놀화합물 변화를 관찰한 결과는 Table 8과 같다. 총 7종의 페놀화합물이 정량되었으며, 섬애 약쑥 주정추출물의 첨가 유무에 따라 페놀화합물의 종류 및 함량에 차이를 보였다. 그 중 chlorogenic acid의 경우 $\mathrm{SE}$ 및 $\mathrm{SM}$ 시료에서 각각 $35.00-35.96 \mathrm{mg} / 100 \mathrm{~mL}$ 및
$36.24-36.72 \mathrm{mg} / 100 \mathrm{~mL}$ 로 페놀화합물 중 가장 높은 함량이 었으나, CO 및 SW시료에서는 발효기간 동안 $0.90 \mathrm{mg} / 100$ $\mathrm{mL}$ 이하로 함량이 낮았다. 함량에는 차이가 있었으나 이러 한 경향은 caffeic acid, coumaric acid, naringin 및 apigenin에 서도 동일하였다. Naringin은 SE와 SM시료에서만 19.50$33.16 \mathrm{mg} / 100 \mathrm{~mL}$ 의 범위로 검출되었으며, 발효기간이 경과 함에 따라 감소하는 경향이었다. 반면 homogentisic acid는 섬애약쑥 물추출물을 첨가한 $\mathrm{SW}$ 시료에서 가장 높게 정량 되어 $1.38-2.52 \mathrm{mg} / 100 \mathrm{~mL}$ 의 범위였다. Pyrogallol은 모든 시료에서 $9.40-11.63 \mathrm{mg} / 100 \mathrm{~mL}$ 의 범위로 발효 $15-20$ 일에 미량 감소하였다가 다시 증가하는 경향이었으나 그 차이가 크지 않았다.

Lee 등(31)은 에탄올 농도를 달리한 상황버섯 추출물의 페놀성 화합물을 측정한 결과 열수추출물에서는 페놀화합 물이 검출되지 않았으며, 에탄올 농도에 따라 검출여부가 상이하였으나 중간농도 에탄올추출물에서 1.158-1.775 $\mathrm{mg} / \mathrm{g}$ 으로 높은 함량이었다고 보고한 바 있다. 또한 Kang 등(9)은 전처리 방법을 달리한 섬애약쑥 에탄올추출물의

Table 8. Changes in phenolic acids of Seomaeyaksuk (Artemisia argyi H.) ethanol extract added vinegar

\begin{tabular}{|c|c|c|c|c|c|c|c|c|c|}
\hline & & & & & & & & & $/ 100 \mathrm{~m}$ \\
\hline $\begin{array}{l}\text { Sample } \\
\text { code } 1\end{array}$ & $\begin{array}{l}\text { Fermentation } \\
\text { periods (days) }\end{array}$ & Pyrogallol & Homogentisic acid & Chlorogenic acid & Caffeic acid & Coumaric acid & Naringin & Apigenin & Total \\
\hline & 0 & $10.31 \pm 0.06^{26 b 3)}$ & $0.66 \pm 0.03^{b}$ & $\mathrm{ND}^{4)}$ & ND & $\mathrm{ND}$ & ND & $\mathrm{ND}$ & 14.97 \\
\hline & 10 & $10.63 \pm 0.05^{\mathrm{bc}}$ & $0.70 \pm 0.04^{b}$ & $0.84 \pm 0.00$ & $0.21 \pm 0.01$ & $\mathrm{ND}$ & $\mathrm{ND}$ & $\mathrm{ND}$ & 12.38 \\
\hline $\mathrm{CO}$ & 15 & $10.39 \pm 0.04^{b}$ & $0.50 \pm 0.04^{\mathrm{a}}$ & $0.84 \pm 0.00$ & $0.21 \pm 0.00$ & $\mathrm{ND}$ & $\mathrm{ND}$ & ND & 11.94 \\
\hline & 20 & $9.40 \pm 0.01^{\mathrm{a}}$ & $0.66 \pm 0.03^{b}$ & $0.82 \pm 0.00$ & $0.39 \pm 0.01$ & $\mathrm{ND}$ & $\mathrm{ND}$ & $\mathrm{ND}$ & 11.27 \\
\hline & 25 & $11.36 \pm 0.07^{\mathrm{c}}$ & $0.94 \pm 0.04^{\mathrm{c}}$ & $0.85 \pm 0.00$ & $0.55 \pm 0.01$ & $\mathrm{ND}$ & $\mathrm{ND}$ & ND & 13.70 \\
\hline & 0 & $10.61 \pm 0.12^{b}$ & $0.73 \pm 0.01^{c}$ & $35.00 \pm 1.35^{\mathrm{a}}$ & $1.39 \pm 0.10^{\mathrm{a}}$ & $0.10 \pm 0.01^{\mathrm{a}}$ & $33.14 \pm 0.11^{\mathrm{e}}$ & $0.09 \pm 0.01^{\mathrm{c}}$ & 81.06 \\
\hline & 10 & $11.08 \pm 0.15^{\mathrm{c}}$ & $0.41 \pm 0.01^{\mathrm{a}}$ & $35.05 \pm 0.41^{\mathrm{a}}$ & $1.36 \pm 0.00^{\mathrm{a}}$ & $0.10 \pm 0.01^{\mathrm{a}}$ & $25.84 \pm 0.24^{\mathrm{d}}$ & $0.07 \pm 0.01^{\mathrm{ab}}$ & 73.91 \\
\hline SE & 15 & $11.83 \pm 0.48^{\mathrm{d}}$ & $0.53 \pm 0.02^{\mathrm{b}}$ & $35.96 \pm 0.49^{\mathrm{a}}$ & $1.64 \pm 0.00^{b}$ & $0.11 \pm 0.01^{\mathrm{a}}$ & $24.43 \pm 0.19^{c}$ & $0.08 \pm 0.01^{\mathrm{bc}}$ & 74.58 \\
\hline & 20 & $9.53 \pm 0.02^{\mathrm{a}}$ & $0.78 \pm 0.04^{c}$ & $35.13 \pm 0.37^{\mathrm{a}}$ & $1.92 \pm 0.01^{\mathrm{c}}$ & $0.11 \pm 0.01^{\mathrm{a}}$ & $20.74 \pm 1.43^{\mathrm{b}}$ & $0.06 \pm 0.01^{\mathrm{a}}$ & 68.27 \\
\hline & 25 & $11.39 \pm 0.09^{\mathrm{c}}$ & $1.15 \pm 0.06^{d}$ & $35.83 \pm 0.05^{\mathrm{a}}$ & $2.14 \pm 0.01^{\mathrm{d}}$ & $0.11 \pm 0.01^{\mathrm{a}}$ & $19.50 \pm 0.36^{\mathrm{a}}$ & $0.07 \pm 0.01^{\mathrm{ab}}$ & 70.19 \\
\hline & 0 & $10.30 \pm 0.05^{\mathrm{a}}$ & $1.38 \pm 0.03^{b}$ & $0.82 \pm 0.01^{\mathrm{a}}$ & $0.21 \pm 0.01^{\mathrm{a}}$ & $\mathrm{ND}$ & $\mathrm{ND}$ & $\mathrm{ND}$ & 12.71 \\
\hline & 10 & $10.67 \pm 0.04^{b}$ & $1.39 \pm 0.05^{\mathrm{b}}$ & $0.88 \pm 0.01^{b}$ & $0.79 \pm 003^{b}$ & $\mathrm{ND}$ & $\mathrm{ND}$ & $\mathrm{ND}$ & 13.73 \\
\hline SW & 15 & $10.94 \pm 0.04^{\mathfrak{c}}$ & $1.28 \pm 0.06^{\mathrm{a}}$ & $0.89 \pm 0.01^{b}$ & $0.85 \pm 0.04^{\mathrm{bc}}$ & $\mathrm{ND}$ & $\mathrm{ND}$ & $\mathrm{ND}$ & 13.96 \\
\hline & 20 & $11.27 \pm 0.01^{\mathrm{d}}$ & $1.90 \pm 0.05^{\mathrm{c}}$ & $0.89 \pm 0.01^{b}$ & $0.81 \pm 0.00^{\mathrm{cd}}$ & $\mathrm{ND}$ & $\mathrm{ND}$ & $\mathrm{ND}$ & 14.87 \\
\hline & 25 & $11.52 \pm 0.05^{\mathrm{e}}$ & $2.52 \pm 0.04^{d}$ & $0.90 \pm 0.01^{b}$ & $0.87 \pm 0.04^{\mathrm{d}}$ & $\mathrm{ND}$ & $\mathrm{ND}$ & $\mathrm{ND}$ & 15.81 \\
\hline & 0 & $10.84 \pm 0.02^{b}$ & $1.50 \pm 0.02^{\mathrm{d}}$ & $36.24 \pm 0.86^{\mathrm{a}}$ & $1.41 \pm 0.31^{\mathrm{a}}$ & $0.05 \pm 0.00^{\mathrm{a}}$ & $33.16 \pm 0.35^{\mathrm{c}}$ & $0.10 \pm 0.01^{b}$ & 83.30 \\
\hline & 10 & $11.63 \pm 0.01^{\mathrm{d}}$ & $0.73 \pm 0.03^{\mathrm{a}}$ & $36.54 \pm 0.09^{\mathrm{ab}}$ & $1.67 \pm 0.02^{\mathrm{a}}$ & $0.09 \pm 0.01^{b}$ & $25.36 \pm 0.15^{b}$ & $0.07 \pm 0.01^{\mathrm{a}}$ & 76.09 \\
\hline SM & 15 & $9.53 \pm 0.01^{\mathrm{a}}$ & $0.96 \pm 0.05^{b}$ & $36.72 \pm 0.08^{\mathrm{ab}}$ & $2.06 \pm 0.12^{b}$ & $0.10 \pm 0.02^{\mathrm{b}}$ & $23.01 \pm 0.19^{\mathrm{a}}$ & $0.07 \pm 0.01^{\mathrm{a}}$ & 72.45 \\
\hline & 20 & $11.11 \pm 0.09^{c}$ & $1.32 \pm 0.07^{\mathrm{c}}$ & $36.55 \pm 0.03^{\mathrm{ab}}$ & $2.33 \pm 0.16^{\mathrm{bc}}$ & $0.09 \pm 0.00^{\mathrm{b}}$ & $21.55 \pm 1.50^{\mathrm{a}}$ & $0.07 \pm 0.01^{\mathrm{a}}$ & 73.02 \\
\hline & 25 & $11.58 \pm 0.21^{\mathrm{d}}$ & $1.77 \pm 0.05^{\mathrm{e}}$ & $37.18 \pm 0.12^{b}$ & $2.49 \pm 0.03^{\mathrm{c}}$ & $0.10 \pm 0.02^{\mathrm{b}}$ & $21.23 \pm 1.48^{\mathrm{a}}$ & $0.08 \pm 0.01^{\mathrm{a}}$ & 74.43 \\
\hline
\end{tabular}

\footnotetext{
${ }^{1)}$ Refer to the Table 2 .

${ }^{2)}$ Each value represents mean $\pm \mathrm{SD}, \mathrm{n}=3$.

${ }^{3) \text { ate }}$ Means with different superscript in the same sample code are significantly different at $p<0.05$.

${ }^{4)} \mathrm{ND}$, not detected
} 
총 페놀화합물 함량을 조사한 결과 덖음 쑥의 경우 30-90\% 의 에탄올추출물 중 $70 \%$ 에탄올추출물에서 함량이 가장 높았으며, 재료나 조건에 따라 차이는 있으나 중간에탄올 농도에서 페놀의 추출이 효과적이라고 보고하였다. 따라 서, 본 연구에서도 $70 \%$ 주정으로 섬애약쑥을 추출하여 페 놀화합물들이 효과적으로 용출된 것으로 생각되며, 섬애약 쑥 주정추출물을 첨가함으로써 총 페놀화합물의 종류 및 총량에도 영향을 주는 것으로 보아 최종 제품의 유효성분에 기여할 것으로 예상된다.

\section{Jaceosidin 및 eupatilin 함량}

섬애약쑥 추출물의 형태를 달리한 식초의 jaceosidin과 eupatilin 함량을 분석한 결과는 Table 9와 같다. 섬애약쑥 주정추출물을 첨가한 $\mathrm{SE}$ 및 $\mathrm{SM}$ 시료에서는 jaceosidin과 eupatilin이 검출되었으나 주정추출물을 첨가하지 않은 $\mathrm{CO}$ 및 $\mathrm{SW}$ 시료에서는 검출되지 않았다. Jaceosidin은 $\mathrm{SE}$ 와 $\mathrm{SM}$ 시료에서 발효 전에는 각각 $10.78 \mathrm{mg} / \mathrm{L}$ 과 $11.09 \mathrm{mg} / \mathrm{L}$ 로 서로 차이가 없었으며, eupatilin도 각각 $5.73 \mathrm{mg} / \mathrm{L}$ 과 5.65 $\mathrm{mg} / \mathrm{L}$ 로 유사한 함량이었다. 발효기간이 경과함에 따라 이 들의 함량은 점차 감소하여 jaceosidin은 $\mathrm{SE}$ 시료에서 발효 25 일에 $6.88 \mathrm{mg} / \mathrm{L}$ 로 발효 0 일에 비해 $36.1 \%$ 가 감소하였고 $\mathrm{SM}$ 시료는 $6.49 \mathrm{mg} / \mathrm{L}$ 로 $41.4 \%$ 감소하였다. Eupatilin도 동일 한 경향으로 $\mathrm{SE}$ 와 $\mathrm{SM}$ 시료에서 각각 발효 25 일에는 2.24 $\mathrm{mg} / \mathrm{L}$ 와 $2.23 \mathrm{mg} / \mathrm{L}$ 로 감소하였다.

홍삼 농축액이 첨가된 쌀 식초 제조시 초산 발효가 완료 된 식초에 홍삼 농축액을 첨가하고 20 일 동안 정치시킴으 로써 조사포닌의 잔존율은 약 $72 \%$ 이며, 초산 발효 전에 홍삼 농축액을 첨가하였을 때는 약 $18 \%$ 로 더 잔존율이 낮은데 이는 식초의 낮은 $\mathrm{pH}$ 로 인해 사포닌 배당체 구조가 분해되고 산가수분해되기 때문이라는 보고(32)가 있는데, 본 연구의 결과에서도 jaceosidin과 eupatilin이 초산 발효로 생성되는 산의 영향을 받아 분해됨으로써 그 함량이 감소된 것으로 추정된다.

Jaceosidin과 eupatilin은 플라보노이드의 일종으로 쑥에 비교적 풍부하게 존재하며 암세포의 생장억제, 항암효과 및 항산화 효능 등이 있는 것으로 알려져 있다(8). Ryu 등 (33)은 인체 혈액암세포(HL-60)에서 eupatilin은 $300 \mu \mathrm{M}$ 까 지 농도 의존적으로 세포 사멸을 유도하였으며, DNA 합성 의 지표인 thymidine 흡수를 억제한다고 하였다. 또한, Kim 등(34)은 jaceosidin 및 eupatilin이 $5 \mathrm{\mu g} / \mathrm{mL}$ 농도에서 각각 64.6 및 $25.8 \%$ 의 LDL-산화 억제효과가 있으며, jaceosidin 은 $100 \mu \mathrm{M}$ 의 농도에서 $18 \%$ 정도의 $\mathrm{DPPH}$ 라디칼 소거활성 을 보인다고 하였다. 본 연구에서 발효 25 일 후 jaceosidin 및 eupatilin의 잔존량은 각각 약 $200 \mu \mathrm{M}$ 및 $70 \mu \mathrm{M}$ 정도의 농도로 상기의 연구결과들과 비교해 볼 때 섬애약쑥 식초의 생리활성에 기여할 것으로 생각되어지며, 향후 실질적인 효능평가가 필요할 것으로 판단된다.
Table 9. Changes in jaceosidin and eupatilin of Seomaeyaksuk (Artemisia argyi H.) ethanol extract added vinegar

\begin{tabular}{|c|c|c|c|}
\hline $\begin{array}{l}\text { Sample } \\
\text { code }^{1)}\end{array}$ & $\begin{array}{l}\text { Fermentation period } \\
\text { (day) }\end{array}$ & Jaceosidin & Eupatilin \\
\hline \multirow{5}{*}{$\mathrm{CO}$} & 0 & $\mathrm{ND}^{2)}$ & ND \\
\hline & 10 & $\mathrm{ND}$ & $\mathrm{ND}$ \\
\hline & 15 & $\mathrm{ND}$ & $\mathrm{ND}$ \\
\hline & 20 & $\mathrm{ND}$ & ND \\
\hline & 25 & $\mathrm{ND}$ & $\mathrm{ND}$ \\
\hline \multirow{5}{*}{ SE } & 0 & $10.78 \pm 0.39^{3 /(4)}$ & $5.73 \pm 0.29^{\mathrm{e}}$ \\
\hline & 10 & $9.96 \pm 0.01^{\mathrm{c}}$ & $4.50 \pm 0.22^{\mathrm{d}}$ \\
\hline & 15 & $9.63 \pm 0.29^{c}$ & $4.16 \pm 0.01^{\mathrm{c}}$ \\
\hline & 20 & $8.51 \pm 0.61^{b}$ & $3.60 \pm 0.02^{b}$ \\
\hline & 25 & $6.88 \pm 0.13^{\mathrm{a}}$ & $2.24 \pm 0.17^{\mathrm{a}}$ \\
\hline \multirow{5}{*}{ SW } & 0 & ND & ND \\
\hline & 10 & $\mathrm{ND}$ & ND \\
\hline & 15 & $\mathrm{ND}$ & $\mathrm{ND}$ \\
\hline & 20 & $\mathrm{ND}$ & ND \\
\hline & 25 & ND & ND \\
\hline \multirow{5}{*}{ SM } & 0 & $11.09 \pm 0.45^{\mathrm{d}}$ & $5.65 \pm 0.18^{d}$ \\
\hline & 10 & $10.10 \pm 0.51^{\mathrm{c}}$ & $4.51 \pm 0.17^{\mathrm{c}}$ \\
\hline & 15 & $9.71 \pm 0.23^{\mathrm{c}}$ & $4.29 \pm 0.49^{c}$ \\
\hline & 20 & $8.55 \pm 0.48^{b}$ & $3.15 \pm 0.17^{b^{\star 55}}$ \\
\hline & 25 & $6.49 \pm 0.19^{\mathrm{a}}$ & $2.23 \pm 0.15^{\mathrm{a}}$ \\
\hline
\end{tabular}

${ }^{1)}$ Refer to the Table 2.

${ }^{2)} \mathrm{ND}$, not detected.

${ }^{3)}$ Each value represents mean \pm SD, $n=3$,

${ }^{4)-2}$ Means with different superscript in the same sample code are significantly different at $\mathrm{p}<0.05$.

${ }^{57}$ Means with different superscript in the same fermentation days are significantly different at $\mathrm{p}<0.05$.

\section{요 약}

본 연구에서는 섬애약쑥의 유효성분인 jaceosidin과 eupatilin을 함유하는 식초의 제조 가능성을 확인하기 위해 섬애약쑥 $70 \%$ 주정추출물을 첨가하여 식초를 제조하였으 며, 물추출물 첨가군과 그 품질특성을 비교하였다. 모든 실험군은 동량의 $10 \%$ 맥아추출물을 첨가하였으며, 여기에 동량의 정제수와 주정을 혼합한 것을 대조군 $(\mathrm{CO})$, 정제수 와 섬애약쑥 주정추출물을 혼합한 것을 $\mathrm{SE}$, 주정과 섬애약 쑥 물추출물을 혼합한 것을 $\mathrm{SW}$, 섬애약쑥 물추출물 및 주정 추출물을 혼합한 것을 $\mathrm{SM}$ 군으로 구분하여 각각의 발효기 질을 제조하였다. 최종 혼합물의 주정 농도는 $6 \%$ 로 조절하 였으며, 각각의 발효기질 $3 \mathrm{~L}$ 에 종배양한 초산균액을 $3 \%$ 접종하고, $30^{\circ} \mathrm{C}$ 에서 정치배양하면서 발효 10 일부터 5 일간 
격으로 25 일까지 시료를 취하였다. 25 일간 발효한 섬애약 쑥 식초의 $\mathrm{L}$ 값은 26.5-46.6, a 값은 -0.4-3.1이었고, $\mathrm{b}$ 값은 5.7-12.4의 범위였다. 최종 산도의 경우 3.60-4.44\% 였으며, 섬애약쑥 주정추출물이 첨가된 $\mathrm{SE}$ 및 $\mathrm{SM}$ 시료는 발효 20 일 이후부터 급격히 산도가 증가하여 발효 25 일에는 SM시료 에서 가장 높았다. 유리당은 fructose 및 glucose 두 종류가 정 량되었고 발효기간 동안 감소하여 발효 25 일차에 각각 0.13-0.22 g/100 mL 및 0.18-0.48 g/100 mL이었다. Acetic acid는 주요 유기산으로 발효 25일에 3,638.51-4,532.90 $\mathrm{mg} / 100 \mathrm{~mL}$ 범위였다. 페놀화합물들은 섬애약쑥 주정추출 물의 첨가 유무에 따라 검출여부 및 함량에 차이가 있었는 데, 주정추출물이 첨가된 시료에서는 총 7종의 페놀화합물 이 검출된 반면 대조군과 물추출물이 첨가된 시료에서는 4종만이 검출되었다. Jaceosidin과 eupatilin은 섬애약숙 주 정추출물을 첨가한 $\mathrm{SE}$ 및 $\mathrm{SM}$ 시료에서만 검출되었는데 발 효기간이 경과할수록 점차 감소하여 발효 25 일차에 jaceosidin은 각각 $6.88 \mathrm{mg} / \mathrm{L}$ 와 $6.49 \mathrm{mg} / \mathrm{L}$ 였으며, eupatilin은 각각 $2.24 \mathrm{mg} / \mathrm{L}$ 및 $2.23 \mathrm{mg} / \mathrm{L}$ 였다. 이상의 결과부터 섬애약 쑥 주정 추출물을 첨가함으로써 25일간의 초산발효 단일 과정을 통해 식초로서 적합한 산도를 가지며, 유기산과 페 놀화합물의 함량이 더 높고 유효성분으로 jaceosidin과 eupatilin을 함유하는 식초의 제조가 가능하였다.

\section{References}

1. Baek SY, Lee CH, Park YK, Choi HS, Mun JY, Yeo SH (2015) Quality characteristics of fermented vinegar prepared with the detoxified Rhus verniciflua extract. Korean J Food Preserv, 22, 674-682

2. Shin EH (2015) Quality Characteristics of vinegar using Wasabi japonica matsum leaves. Korean J Culinary Res, 21, 255-263

3. Hong SM, Kang MJ, Lee JH, Jeong JH, Kown SH, Seo KI (2012) Production of vinegar using Rubus coreanus and Its antioxidant activities. Korean J Food Preserv, 19, 594-603

4. Kim KO, Kim SM, Kim SM, Kim DY, Jo DJ, Yeo SH, Jeong YJ, Kwon JH (2013) Physicochemical properties of commercial fruit vinegars with different fermentation methods. J Korean Soc Food Sci Nutr, 42, 736-742

5. Kang KM, Lee SH (2013) Effects of extraction methods on the antioxidative activity of Artemisia sp.. J Korean Soc Food Sci Nutr, 42, 1249-1254

6. Seo KS, Yun KW (2011) Antimicrobial activity and total polyphenol content of extracts from Artemisia capillaris Thunb. and Artemisia iwayomogi Kitam. used as Injin.
Korean J plant Res, 24, 10-16

7. Lee SD, Park HH, Kim DW, Bang BH (2000) Bioactive constituents and utilities of Artemisia sp. as medicinal herb and foodstuff. Korean J Food Nutr, 13, 490-505

8. Ha GJ, Lee DS, Seung TW, Park CH, Park SK, Jin DE, Kim NK, Shin HY, Heo HJ (2015) Anti-amnesic and neuroprotective effects of Artemisia argyi H. (seomae mugwort) extracts. Korean J food Sci Technol, 47, 380-387

9. Kang JR, Kang MJ, Choi MH, Byun HU, Shin JH (2017) Physicochemical characteristics of ethanol extract from Artemisia Argyi H. using different preparation methods. J Life Sci, 27, 23-31

10. Hwang CR, Seo WT, Bae WY, Kang MJ, Shin JH (2014) Physicochemical characteristics and biological activities of Artemisia Argyi H.. J Life Sci, 24, 377-385

11. Ahn JB, Hur JN, Jung HG Park JH (2012) Study on the growth environment of 'Gangwha-mugwort' through the climatological characteristic analysis of Gangwha region. Korean J Agricultural Forest Meteorology, 14, 71-78

12. Park EK, Kwon BM, Jung IK, Kim JH (2014) Hypoglycemic and antioxidant effects of jaceosidin in streptozotocin-induced diabetic mice. J Nutr Health, 47, 313-320

13. Choi MH, Kang JR, Sim HJ, Kang MJ, Seo WT, Bea WY, Shin JH (2015) Physicochemical characteristics and antioxidant activity of Sumaeyaksuk depending on harvest times and processing methods. Korean J Food Preserv, 22, 399-407

14. Hwang CR, Seo WT, Jung MJ, Shin JH (2013) Antioxidant activity of the Sumaeyaksuk tea extracts prepared with different drying and extract conditions. Korean J Food Preserv, 20, 546-553

15. Lee SH, Kim JC (2009) A comparative analysis for main components change during natural fermentation of persimmon vinegar. J Korean Soc Food Sci Nutr, 38, 372-376

16. Lee GE, Kim SM, Huh CK, Cho IK, Kim YD (2015) Comparison of quality properties and identification of acetic acid bacteria for black waxy rice vinegar. Korean J Food Preserv, 22, 443-451

17. Lee SW, Kwon JH, Yoon SR, Woo SM, Jang SY, Yeo SH, Choi JH, Jeong YJ (2010) Quality characteristics of brown rice vinegar by different yeasts and fermentation condition. J Korean Soc Food Sci Nutr, 39, 1366-1372

18. Seo JH, Kim YJ, Lee KS (2003) Comparison of 
physicochemical characteristics of fruit vinegars produced from two-stage fermentation. Food Industry and Nutrition, 8, 40-44

19. Lee JC, Han WC, Lee JH, Jang KH (2012) Quality evaluation of vinegar manufactured using rice and Rosa rugosa Thunb.. Korean J Food Sci Technol, 44, 202-206

20. Kwon SH, Jeong EJ, Lee GD, Jeong YJ (2000) Preparation method of fruit vinegars by two stage fermentation and beverages including vinegar. Food Industry and Nutrition, 5, 18-24

21. Na HS, Choi GC, Yang SI, Lee JH, Cho JY, Ma SJ, Kim JY (2013) Comparison of characteristics in commercial fermented vinegars made with different ingredients. Korean J Food Preserv, 20, 482-487

22. KFDA (2008) Korea Food Standard Code. Korea Food Drug Administration, Korea, 21, 1-2

23. Park CS, Kwon CJ, Choi MA, Park GS, Choi KH (2002) Antibacterial activities of Cordyceps spp., mugwort and pine needle extracts. Korean J Food Preserv, 9, 102-108

24. Park SK, Park JC (1994) Antimicrobial activity of extracts and coumaric acid isolated from Artemisia princeps var. orientalis. Korean J Biotechnol Bioeng, 9, 506-511

25. Jeong YJ, Seo JH, Park NY, Shin SR, Kim KS (1999) Changes in the components of persimmon vinegars by two stages fermentation (1). Korean J Postharvest Sci Technol, 6, 228-232

26. Jang SY, Shin KA, Jeong YJ (2010) Quality characteristics of apple vinegar by agitated and static cultures. J Korean Soc Food Sci Nutr, 39, 308-312

27. Moon SY, Chung HC, Yoon HN (1997) Comparative analysis of commercial vinegars in physiochemical properties, minor components and organolepic tastes. Food Sci Technol, 29, 663-670

28. Furukawa S, Ueda R (1963) Studies on non-volatile organic acid in vinegar (I): Contents of non-volatile organic acids in commercial vinegars. $\mathrm{J}$ Ferment Technol, 41, 14-19

29. Joo KH, Cho MH, Park KJ, Jeong SW, Lim JH (2009) Effects of fermentation method and brown rice content of quality characteristics of brown rice vinegar. Korean J Food Preserv, 16, 33-39

30. Yi MR, Hwang JH, Oh YS, Oh HJ, Lim SB (2014) Quality characteristics and antioxidant acitivity of immature Citrus unshiu vinegar. J Korean Soc Food Sci Nutr, 43, 250-257

31. Lee KH, Kwon HJ, Chun SS, Kim JH, Cho YJ, Cha WS (2006) Biological activities of extracts from Phellinus linteus. J Korean Soc Appl Biol Chem, 49, 298-303

32. Kim DK, Baik MY, Kim HK, Hahm YT, Kim BY (2012) Manufacture of the red ginseng vinegar fermented with red ginseng concentrate and rice wine, and its quality evaluation. Korean J Food Sci Technol, 44, 179-184

33. Ryu SN, Han SS, Yang JJ, Jeong HG, Kang SS (2005) Variation of eupatilin and jaceosidin content of mugwort. Korean J Crop Sci, 50, 204-207

34. Kim MJ, Han JM, Jin YY, Baek NI, Bang MH, Chung HG, Choi MS, Lee KT, Sok DE, Jeong TS (2008) In vitro antioxidant and anti-inflammatory activities of jaceosidin from Artemisia princeps Pampanini cv. Sajabal. Arch Pharm Res, 31, 429-437 